\title{
Comparative evaluation of the root powder of Lonchocarpus cyanescens for the control of Sitophilus zeamais (motschulsky) in maize and wheat
}

\author{
Chidi Emmanuel Akunne ${ }^{1,}$, , Victory Ada Ezu ${ }^{1}$, Tochukwu Chinedu Mogbo ${ }^{1}$, Benjamin Uzonna Ononye ${ }^{1}$, \\ Uche Ngenegbo. ${ }^{2}$ \\ ${ }^{1}$ Department of Zoology, Nnamdi Azikiwe University Awka, Anambra State, Nigeria \\ ${ }^{2}$ Department of Parasitology \& Entomology, Nnamdi Azikiwe University Awka, Anambra State, Nigeria \\ Email address: \\ chidiknne@yahoo.com (C. E. Akunne) \\ To cite this article: \\ Chidi Emmanuel Akunne, Victory Ada Ezu, Tochukwu Chinedu Mogbo, Benjamin Uzonna Ononye, Uche Ngenegbo. Comparative \\ Evaluation of the Root Powder of Lonchocarpus Cyanescens for the Control of Sitophilus Zeamais (Motschulsky) in Maize and Wheat. \\ American Journal of Life Sciences. Vol. 2, No. 2, 2014, pp. 53-56. doi: 10.11648/j.ajls.20140202.13
}

\begin{abstract}
The root powder of Lonchocarpus cyanescens was evaluated under ambient laboratory conditions for its insecticidal properties against adult Sitophilus zeamais on maize and wheat grains. The root powders of $L$. cyanescens were applied separately on maize and wheat grains in the concentrations of $0 \mathrm{~g}$ (Control), $10 \mathrm{~g}, 15 \mathrm{~g}, 20 \mathrm{~g}, 25 \mathrm{~g}$, and $30 \mathrm{~g}$ respectively. Daily mortality count of adult $S$. zeamais was recorded for 3 weeks and numbers of dead $S$. zeamais obtained from each concentration and the control were compared. The data were statistically analysed and results reported. In both grains, all concentrations of Lonchocarpus cyanescens recorded higher mortality than the control. The root powder application at $30 \mathrm{~g}$ concentration gave the highest mortality of $S$. zeamais while lowest mortality of $S$. zeamais was recorded in maize and wheat grains treated with $10 \mathrm{~g}$ concentration during the exposure period. Statistically, grains treated with root powders were significantly $(\mathrm{P}<0.05)$ different from the control in adult mortality. The root powder of L. cyanescens could be used as protectants in the storage of maize and wheat grains.
\end{abstract}

Keywords: Evaluation, Maize, Wheat, Lonchocarpus Cyanescens, Sitophilus Zeamais

\section{Introduction}

Maize[Zea mays L. Gramineae] the American Indian word for corn, literally means "that which sustains life" (Guria, 2006; Oladejo and Adetunji, 2012) originated from the South and Central America and was introduced to West Africa by the Portuguese in the $10^{\text {th }}$ century (Iken and Amusa, 2004). Maize is the staple food of millions of people inhabiting the tropical region including Nigeria and is one of the important cereal grains nourishing the people (Guria, 2006). It is estimated that several million people derive their protein and calorie (11.1 g and $342 \mathrm{Kcal} /$ day) requirement from maize grain which accounts for about 15 to 56 per cent of the total daily calories in diets of people in about 25 developing countries (Gopalan et al., 1999; Prasanna, 2001). Maize is a multipurpose crop because every part (grain, leaves, stalk, tassel and cob) of its plant has economic value and could be used for the production of large variety of food and non food products (IITA, 2001). Maize can be classified according to the structure of the grain. We have sweet corn, flint corn, popcorn, dent corn, soft or flour corn and pod corn (Oladejo and Adetunji, 2012). It started as a subsistence crop and has gradually become a more important crop as it has risen to a commercial crop on which many agro-based industries depend on as raw materials (Iken and Amusa, 2004). Besides this, it is also used as industrial starches and in pharmaceuticals as dextrose, maltose, ethanol and corn oil (Guria, 2006). Maize is highly yielding, easy to process, readily digested and cost less than other cereals. It is also a versatile crop, allowing it to grow across a range of agro ecological zones (IITA, 2001). It is an important source of carbohydrate if eaten in the immature state, provides useful quantities of Vitamin A and C. It is the third most important cereal after wheat and rice globally and the most widely 
distributed (Siwale et al., 2009).

Wheat is a substantial part of the diet of several billions of people globally, (Kumar et al., 2011). It is the most important stable food crop for more than one third of the world population and contributes more calories and proteins to the world diet than any other cereal crops (AbdEl-Haleem, 1998; Adams, 2002; Shewry, 2009). There are many reports of the association of wheat, and particularly wheat proteins, with medical conditions, ranging from improbable reports in the popular press to scientific studies in the medical literature (Cartera et al., 2006).

Insects such as maize weevil can cause substantial damage to stored maize and wheat grains in the tropics and subtropics and are the major constraint to their utilization (Akob and Ewete, 2007; Yigezu et al., 2009). The adults and larvae of the weevils feed on undamaged grains and frequently causes severe powdering, rendering grains unfit for human consumption (Ofuya et al., 2008). In Nigeria, chemical insecticides are widely used in the control of storage insects, its abuse and misuse has several repercussions including acute and chronic poisoning in man, sudden deaths, blindness, skin irritation and pest resurgence in the ecosystem (Akunne and Okonkwo, 2006; Lowenberg-DeBoer and Ibro, 2008; Omoloye, 2008). Insect pests cause substantial damage to stored products throughout the world. In the United States, annual postharvest losses due to insects in corn and wheat are estimated at about $\$ 1.25$ to $\$ 2.5$ billion, accounting for 5 to $10 \%$ of the total value of corn and wheat produced (USDA, 2005). The scientific information on the use of Lonchocarpus cyanescens for the control of insect pest is limited.

The aim of this research is to evaluate the efficacy of root powder of Lonchocarpus cyanescens for the control of $S$. zeamais in wheat and maize. The objectives of the study are to determine the quantity of the root powder of $L$. cyanescens that will achieve the highest mortality of adult $S$. zeamais and to compare the efficacy of the root powder in wheat and maize.

\section{Materials and Method}

\subsection{Sources and Preparation of Plant Materials}

The root of Lonchocarpus cyanescens were harvested from a farm at Ugbene in Awka North Local Government Area of Anambra State. The harvested roots were washed with water to remove sand, chopped into small pieces to allow proper drying. They were dried at room temperature for 7 days to retain the active ingredient. The dried materials were ground into powder in an electric hammer mill. The powder was kept in air tight container to retain the active ingredients and as well to avoid absorbing moisture. The powders were stored in a cool dry place until when needed. The infested and uninfested maize and wheat grains used in this study were obtained from Eke-Awka market in Awka.

\subsection{Experimental Set up}

The uninfested wheat and maize grains were oven-dried for one hour at $100^{\circ} \mathrm{C}$ to rid off insidious infestation of any stage of the insect and allowed to cool. $50 \mathrm{~g}$ each of maize and wheat grains were measured into white transparent plastic containers measuring $12 \mathrm{~cm}$ in diameter with perforated lids to allow ventilation but prevent entry or escape of insects. The experimental root powder of $L$. cyanescens at different concentrations of $0 \mathrm{~g}$ (control), $10 \mathrm{~g}$, $15 \mathrm{~g}, 20 \mathrm{~g}, 25 \mathrm{~g}$ and $30 \mathrm{~g}$ were added separately into the containers holding $50 \mathrm{~g}$ of maize and wheat grains. They were shook vigorously to admix thoroughly. $50 \mathrm{~g}$ of maize and wheat grains not treated with plant material were also measured into the same type of containers and used as control. Each of the treatments was replicated three times.

The adult Sitophilus zeamais were collected from infested maize grains. Twenty newly emerged adult Sitophilus zeamais unsexed were introduced into each of the experimental containers including the controls. The setups were kept in the laboratory cupboards. The time for the infestation was noted and recorded properly. All treatments were arranged in completely randomized design (C.R.D).

\subsection{Data Collection and Statistical Analysis}

Data were generated and recorded from mortality count of adult $S$. zeamais on daily basis for 21 days and were used to determine the most efficient proportions of the powders. Dead weevils were removed and discarded after every count. Data generated on mortality of the weevils due to insecticidal effect of root powders were subjected to analysis of variance (ANOVA) using SPSS computer Software package (version 20) at 0.05 significant levels.

\section{Results}

The results shown in Table 1 and 2 below indicated that the mean mortality of $S$. zeamais in both wheat and maize increased with concentration of the powder. The $30 \mathrm{~g}$ concentration of the root powder produced the highest mean mortality of $S$. zeamais $(0.9048 \pm 0.96)$ in wheat while the control recorded the lowest mean mortality count $(0.0159 \pm 0.13)$. The mortality count in cowpea seeds treated with $15 \mathrm{~g}, 20 \mathrm{~g}, 25 \mathrm{~g}$ and $30 \mathrm{~g}$ concentrations were significantly different from each other as well as from the control but no significant difference exist between the $10 \mathrm{~g}$ of the powder and the control.

Table 2 below indicated that the $30 \mathrm{~g}$ concentration of the root powder of $L$. cyanescens produced the highest mean mortality of $S$. zeamais $(1.127 \pm 1.2)$ in the treated maize while the control recorded the lowest mean mortality count $(0.0159 \pm 0.13)$. The mean mortality count of $S$. zeamais between $15 \mathrm{~g}, 20 \mathrm{~g}, 25 \mathrm{~g}$ and $30 \mathrm{~g}$ concentrations are significantly different from each other as well as from the control but no significant difference existed between the $10 \mathrm{~g}$ of the root powder and the control.

Figure 1a depicted that in both wheat and maize, the 
mortality of $S$. zeamais increased as the root powder concentration is increased. However, in higher concentrations (such as $25 \mathrm{~g}$ and $30 \mathrm{~g}$ ) the mortality in maize was higher. Figure $1 \mathrm{~b}$ showed that there was more mortality of $S$. zeamais in maize than in wheat using $L$. cyanescens root powder. Appendix 1 below indicated that there was a significant difference in mortality of $S$. zeamais brought by $L$. cyanescens concentrations of the root powder $(\mathrm{P}=0.00)$. However, the mortality of $S$. zeamais brought by the root powder and their concentrations does not significantly differ in both seeds $(\mathrm{P}>0.05)$.

Table 1. Mean Mortality Count of Sitophilus zeamais in Wheat Observed for Three Weeks on Various Concentrations of Lonchocarpus cyanescens Root Powder.

\begin{tabular}{cc}
\hline Concentration (in grams) & Mean Mortality Counts \pm SD \\
\hline 10 & $0.16 \pm 0.378^{\mathrm{ab}}$ \\
15 & $0.29 \pm 0.521^{\mathrm{b}}$ \\
20 & $0.54 \pm 0.643^{\mathrm{c}}$ \\
25 & $0.75 \pm 0.983^{\mathrm{d}}$ \\
30 & $0.90 \pm 0.962^{\mathrm{e}}$ \\
Control & $0.02 \pm 0.126^{\mathrm{a}^{*}}$ \\
\hline
\end{tabular}

*Rows sharing similar superscript are not significantly different

Table 2. Mean Mortality Count of Sitophilus zeamais in Maize Observed for Three Weeks on Various Concentrations of Lonchocarpus cyanescens Powder.

\begin{tabular}{cc}
\hline Concentration (in grams) & Mean Mortality Counts \pm SD \\
\hline Control $(0)$ & $0.02 \pm 0.13^{\mathrm{a}}$ \\
10 & $0.19 \pm 0.40^{\mathrm{ab}}$ \\
15 & $0.27 \pm 0.48^{\mathrm{b}}$ \\
20 & $0.51 \pm 0.69^{\mathrm{c}}$ \\
25 & $0.80 \pm 0.88^{\mathrm{d}}$ \\
30 & $1.13 \pm 1.20^{\mathrm{e}}$ \\
\hline
\end{tabular}

*Rows sharing similar superscript are not significantly different

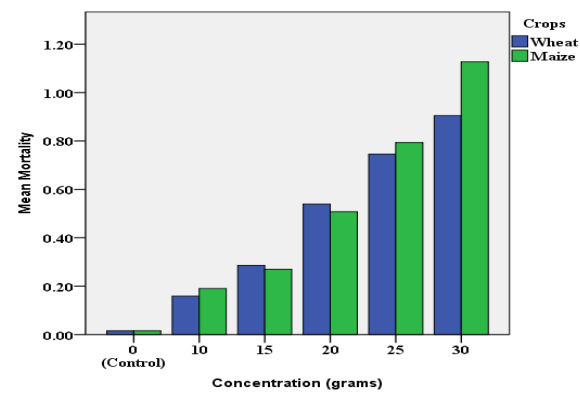

Figure 1a. Showing the mean mortality count of Sitophilus zeamais in maize and wheat on various concentration of Lonchocarpus cyanescens powder.

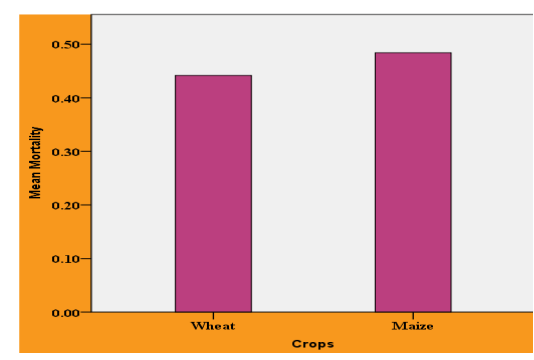

Figure 1b. Showing the total mean mortality of Sitophilus zeamais in wheat and maize by Lonchocarpus cyanescens powder.

\section{Discussion}

This present study on the assessment of the efficacy of root powder of $L$. cyanescens on adult $S$. zeamais showed that the mean mortality count of $S$. zeamais in wheat grains increased with concentration of the root powder. It was observed that the wheat grains treated with $30 \mathrm{~g}$ concentration of the root powder of $L$. cyanescens produced the highest mean mortality of $S$. zeamais $(0.9048 \pm 0.96)$ in wheat while it was lower in $10 \mathrm{~g}$ of the root powder. However, significant difference exists when the mortality of $S$. zeamais were compared between the root powder concentrations $(15 \mathrm{~g}, 20 \mathrm{~g}, 25 \mathrm{~g}$ and $30 \mathrm{~g}$ ).

Similarly, maize grains treated with the various concentrations of the root powder shows highest mean mortality $(1.127 \pm 1.2)$ when $30 \mathrm{~g}$ of the root powder was applied and lower mean mortality $(0.1905 \pm 0.04)$ was recorded in maize grains treated with $10 \mathrm{~g}$ concentration of the root powder of $L$. cyanescens. Significant difference exists between the other concentrations of the powder when compared with the control except for those treated with $10 \mathrm{~g}$ concentration at $5 \%$ level of significance. This supports the fact that powders of plant origin can be used satisfactorily for the control of pests during the storage period (Silva et al. 2003). Ashamo, (2007) also reported an average mortality of $S$. zeamais at 28 days post-treatment at three rates $(0.2,0.4$ and $0.6 / 20 \mathrm{~g}$ of Capsicum frutescens/ maize seeds). Figures $1 \mathrm{a}$ and $1 \mathrm{~b}$ showed that in both wheat and maize, the mortality of $S$. zeamais increased as the root powder concentration is increased. However, in higher concentrations (such as $25 \mathrm{~g}$ and $30 \mathrm{~g}$ ) the mortality in maize was higher. It also showed that there was a significant difference in mortality of $S$. zeamais brought by the various concentrations of the root powder of $L$. cyanescens $(\mathrm{P}=0.00)$. However, the mortality of $S$. zeamais brought by the powder and their concentrations does not significantly differ in both seeds $(\mathrm{P}>0.05)$.

Based on the results, L. cyanescens showed insecticidal potentials against $S$. zeamais and gave protection to stored maize and Wheat grains from damage by adult $S$. zeamais since there was a significant difference between those applied on maize and wheat.

However for best results, higher concentration of $L$. cyanescens powder more than $25-30 \mathrm{~g}$ per $50 \mathrm{~g}$ of maize and wheat should be used.

\section{References}

[1] Abd-El-Haleem S.H.M, Reham M.A, Mohamed S.M.S, Abdel-Aal E.S.M, Sosulski F.W., and Hucl P. (1998). Origins, Characteristics and Potentials of Ancient Wheats, Cereal Foods World, 43: 708-715.

[2] Adams M.L., Lombi E., Zhao F.J, McGrath S.P. (2002). Evidence of Low Selenium Concentrations in UK Breadmaking Wheat Grain. Journal of the Science of Food and Agriculture, 82: 1160-1165. 
[3] Akob, C. A., and Ewete, F. K. (2007). The efficacy of ashes of four locally used plant materials against Sitophilus zeamais (Coleoptera: Curculionidae) in Cameroon. International Journal of Insect Science, 27(1):21-26.

[4] Akunne, C.E. and Okonkwo, N.J. (2006). Pesticides: Their Abuse and Misuse in our Environment. Book of Proceedings of the $3^{\text {rd }}$ Annual National Conference of the Society for Occupational Safety and Environmental Health (SOSEH) Awka 2006. pp..130-132.

[5] Ashamo, M.O. (2007). Evaluation of Contact Toxicity and fumigant effect of some plant powders against Sitophilus zeamais (Mots). Proceedings of the Akure - Humboldt Kellong (3rd SAAT annual conference: Medicinal Plants in Agriculture, the Nigeria Experience, pp. 64-67

[6] Cartera J.W., Madlb R., Padulac F., (2006). Wheat antioxidants suppress intestinal tumor activity in Min mice. Nutrition Research, 26 (1): 33-38.

[7] Gopalan, C., Sastri, R.B.V. and Balasubramanian, S.C. (1999). Nutritive value of Indian foods. NIN, ICMR, Hyderabad.

[8] Guria, P. (2006). Physico-Chemical Properties, Nutritional Quality and Value Addition to Quality Protein Maize (Zea Mays L.). Thesis Submitted to the University of Agricultural Sciences, Dharwad in Partial Fulfillment of the Requirements For The Degree of Master of Home Science in Food Science and Nutrition Department of Food Science and Nutrition College of Rural Home Science, University of Agricultural Sciences, Dharwad December, 70 p.

[9] Iken, J.E., and Amusa, N.A. (2004). Maize Research and Production in Nigeria. African Journal of Biotechnology. 3(6): 302-307.

[10] International Institute of Tropical Agriculture (IITA) (2001). International Institute of Tropical Agriculture, Annual Report on Maize. IITA publication.

[11] Kumar, P., Yadava, R.K., Gollen, B., Kumar, S., Verma, R.K., and Yadav, S. (2011). Nutritional Contents and Medicinal Properties of Wheat: A Review. Life Sciences and Medicine Research, Volume 2011: LSMR-22. pp .1-10

[12] Lowenberg-DeBoer, J. and Ibro, G. (2008). A Study Of The Cowpea Value Chain In Kano State, Nigeria, From A Pro-
Poor and Gender Perspective. A paper commissioned by the GATE Project $\mathrm{p} 56$.

[13] Ofuya, T.I., Idoko, J.E. and Akintewe, L.A. (2008). Ability of Sitophilus zeamais Motschulsky [Coleoptera: Curculonidae] from Four Locations In Nigeria To Infest and Damage Three Varieties of Maize, Zea mays L. Nigerian Journal of Entomology 25:34-39

[14] Oladejo, J.A. and Adetunji M.O. (2012). Economic Analysis of Maize (Zea mays L.) Production in Oyo State of Nigeria. Agricultural Science Research Journals, 2(2):77-83.

[15] Omoloye, A.A. (2008). Fundamentals of Insect Pest Management. Corporate Publishers Lagos. 223p.

[16] Prasanna, B.M., Vasal, S.K., Kassahun, B. and Singh, N.N. (2001). Quality Protein Maize. Current Science, 81(10): 1308-1318.

[17] Shewry, P.R. (2009). The Health grain programme opens new opportunities for improving wheat for nutrition and health. Nutrition Bulletin, 34(2): 225-231.

[18] Silva G. and Lagunes, T. (2003). Control de Sitophilus zeamais (Coleoptera: Curculionidae) Con Polvos Vegetales Solos Yen Mezcla Con Carbonato De Calcio. Ciencia e Investigación Agraria, 30:153

[19] Siwale V., Mbata, K., Mcrobert, J. and Lungu, D. (2009). Comparative resistance of improved maize genotypes and landraces to maize weevil. African Crop Science Journal, 17(1): $1-16$.

[20] USDA, (2005). Integrated Management of Insect Pests in Stored Grain and in Processed Grain Products. Annual Project Report: the Biological Research Unit, Agricultural Research Service, United States Department of Agriculture.

[21] Yigezu A. Yigezu, Corinne E. Alexander, Paul V. Preckel, D.E. Maier, L. J. Mason, C. Woloshuk, J. Lawrenceg, and D.J. Moogh (2009). The Economics of Integrated Insect Pest Management in Stored Corn. A paper presented at the Agricultural and Applied Economics Association 2009 Annual Meeting, July 26-28, 2009, Milwaukee, Wisconsin. pp.1-38 